\title{
Analysis Of Liquidity, Solvency, Activity And Profitability Ratio To Assess The Financial Performance Of PT. Martina Berto Tbk For The Period 2014-2018
}

\author{
Linda Mariana a,1,*, Heru Satria Rukmana $^{\text {b,2 }}$ \\ a Alumni Program Studi Manajemen, STIE Dewantara, Jl. Raya Pemda Bojong Depok Baru III Karadenan Cibinong \\ Bogor, Jawa Barat 16913, Indonesia \\ b Dosen Tetap Program Studi Manajemen, STIE Dewantara, Jl. Raya Pemda Bojong Depok Baru III Karadenan Cibinong \\ Bogor, Jawa Barat 16913, Indonesia \\ ${ }^{1}$ lindamariana1305@yahoo.com *; ${ }^{2}$ rukmanaheru23@yahoo.co.id \\ * corresponding author
}

\section{ARTICLE INFO}

\section{Article History}

Received, 30-Sept-2020

Reviewed, 05-Okt-2020

Published, 31-Okt-2020

\section{Keywords}

Financial Performance;

Liquidation Ratio;

Solvency Ratio;

Ratio Activity;

Profitability Ratio.

\begin{abstract}
This study aims to assess the financial performance of PT Martina Berto Tbk in 2014 to 2018 which is reviewed from financial ratios. Financial ratios used are liquidity, solvency, activity and profitability. This study is quantitative descriptive research. Data collection techniques are performed using documentation methods in the form of secondary data and library assessments. Data analysis techniques are used using financial ratio analysis in the form of a comparison of the company's financial ratio performance with the industry average. The results of this study show that the liquidity ratio consisting of current ratio in 2014 was above the industry average and in 2015-2018 was below the industry average, the quick ratio in 2014-2016 was above the industry average and in 2017-2018 was below the industry average, the cash ratio in 2014 was above the industry average and in 2015-2018 was below the industry average. The solvency ratio consisting of debt to asset ratio in 2014 was below the industry average and in 2015-2018 was above the industry average, the debt to equity ratio in 2014 was below the industry average and in 2015-2018 was above the industry average. The ratio of activities consisting of receivable turn over in 2014-2018 is below the industry average, inventory turn over in 2014-2017 was above the industry average and in 2018 was below the industry average, fixed asset turn over in 20142018 was below the industry average, fixed asset turn over in 20142018 was above the industry average, the total asset turn over in 2014-2018 was below the industry average. The profitability ratio consisting of return on assets in 2014-2018 is below the industry average, return on equity in 2014-2018 is below the industry average and net profit margin in 2014-2018 is below the industry average
\end{abstract}

\section{PENDAHULUAN}

\subsection{Latar Belakang}

Indonesia merupakan salah satu pasar kosmetik yang cukup besar sehingga bisnis ini akan prospektif dan menjanjikan bagi produsen yang ingin mengembangkannya di dalam negeri.

Menurut Menperin Airlangga Hartarto, industri kosmetik di dalam negeri bertambah sebanyak 153 perusahaan pada tahun 2017, sehingga saat ini jumlahnya mencapai lebih dari 760 perusahaan. Dari total tersebut, sebanyak 95 persen industri kosmetik nasional merupakan sektor industri kecil dan menengah (IKM) dan sisanya industri skala besar. Kementerian Perindustrian telah menempatkan industri kosmetik sebagai sektor andalan sebagaimana tertuang dalam Rencana Induk Pembangunan Industri Nasional (RIPIN) tahun 2015-2035.

Dengan perkembangan bisnis sektor kosmetik di Indonesia yang semakin pesat sehingga mempengaruhi daya saing bagi setiap perusahaan untuk meningkatkan operasi, pangsa pasar dan kinerjanya. Bagi emiten, perusahaan harus memberikan rincian laporan keuangan sebagai 
penilaian kinerja keuangan yang selama ini telah dijalankan. PT. Martina Berto Tbk merupakan salah satu perusahaan yang bergerak dibidang manufaktur sektor kosmetik yang menjadi fokus peneliti dalam melakukan penelitian. Berikut ini kondisi laporan keuangan PT Martina Berto Tbk dilihat dari posisi keuangan, penjualan dan laba di tahun 2014-2018.

Tabel 1. Posisi Keuangan dan Penjualan PT Martina Berto Tbk Periode 2014 s/d 2018.

(Dalam Miliar Rupiah)

\begin{tabular}{cccccc}
\hline $\begin{array}{c}\text { Posisi } \\
\text { Keuangan } \\
\begin{array}{c}\text { Dan } \\
\text { Penjualan }\end{array}\end{array}$ & $\mathbf{2 0 1 4}$ & $\mathbf{2 0 1 5}$ & $\mathbf{2 0 1 6}$ & $\mathbf{2 0 1 7}$ & $\mathbf{2 0 1 8}$ \\
\hline Aset & 619,383 & 648,899 & 709,959 & 780,670 & 648,017 \\
Liabilitas & 165,634 & 214,686 & 269,032 & 367,927 & 347,517 \\
Ekuitas & 453,749 & 434,214 & 440,927 & 412,743 & 300,500 \\
Penjualan & 671,399 & 694,783 & 685,444 & 731,577 & 502,518 \\
\hline \multicolumn{7}{c}{ Sumber: }
\end{tabular}

Jika diilihat dari tabel 1.2 posisi keuangan PT Martina Berto Tbk, dilihat dari asetnya pada tahun 2018 mengalami penurunan fluktuatif sebesar Rp648,017 miliar turun $-17 \%$ dari Rp780,670 miliar di tahun 2017. Liabilitas pada tahun 2018 mencapai Rp347,517 miliar turun 5,54\% dari Rp367,927 miliar di tahun 2017. Ekuitas pada tahun 2015,2017 dan 2018 mengalami penurunan di setiap tahunnya dan penurunan ekuitas terbesar terjadi pada tahun 2018 sebesar Rp300,500 miliar turun -27,19\% dari Rp412,743 di tahun 2017.

Penjualan PT Martina Berto Tbk di tahun 2016 dan 2018 mengalami penurunan di setiap tahunnya. Pada tahun 2016 penjualan mencapai Rp685,444 miliar turun -1,34\% dari Rp694,783 miliar di tahun 2015. Pada tahun 2018 penjualan mengalami penurunan fluktuatif sebesar Rp502,518 miliar turun -31,31\% dari Rp731,577 miliar di tahun 2017.

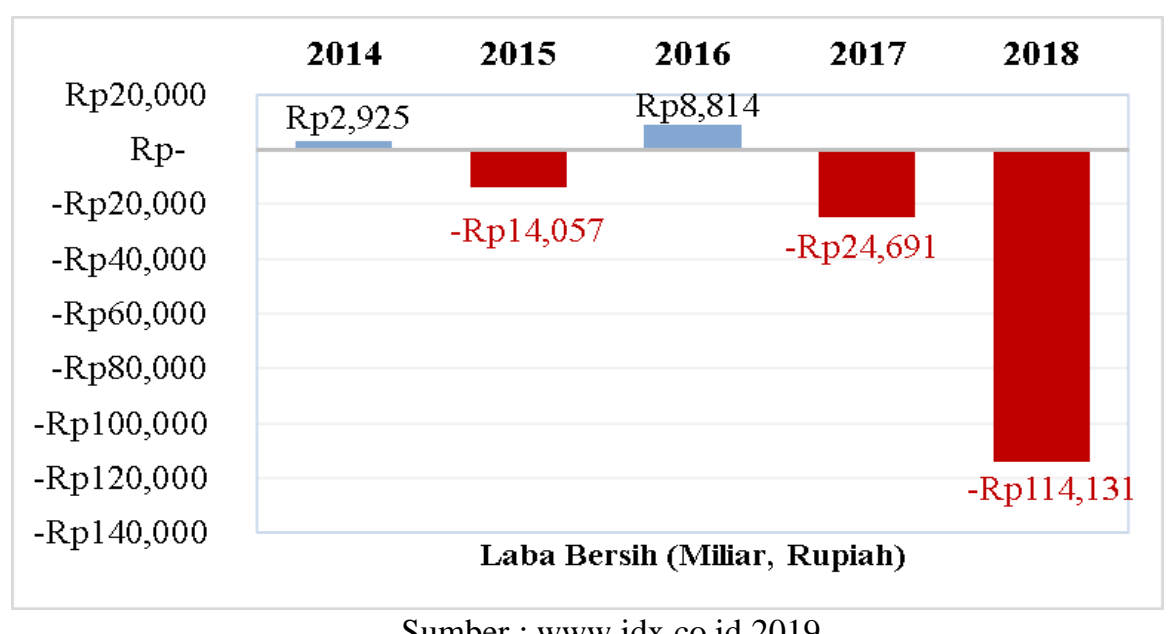

Gambar 1. Grafik Laba Bersih PT Martina Berto Tbk Periode 2014 s/d 2018

Jika diilihat dari gambar grafik 1.2 laba bersih PT Martina Berto Tbk, pada tahun 2015 PT Martina Berto Tbk mengalami rugi bersih tahun berjalan sebesar Rp.14,057 miliar. Penurunan laba bersih tahun berjalan ini terutama disebabkan oleh penurunan marjin laba kotor dan kenaikan biaya operasi.

Pada tahun 2017, biaya pemasaran dan penjualan yang dikeluarkan belum langsung menghasilkan dan menggerus margin perusahaan, sehingga PT Martina Berto Tbk membukukan rugi bersih tahun berjalan sebesar Rp.24,691 miliar dari target laba bersih tahun 2017 sebesar 
Rp.12,00 miliar. Pada tahun 2018, penurunan penjualan lebih besar dari pada penurunan beban overhead dan pemasaran, sehingga PT Martina Berto Tbk membukukan rugi bersih tahun berjalan sebesar Rp.114,131 miliar dari target laba bersih tahun 2018 sebesar Rp.15,00 miliar.

Berdasarkan penjelasan diatas, penulis tertarik untuk melakukan sebuah penelitian dengan judul "Analisis Rasio Likuiditas, Solvabilitas, Aktivitas dan Profitabilitas untuk Menilai Kinerja Keuangan PT Martina Berto Tbk Periode 2014-2018.

\subsection{Ruang Lingkup Permasalahan}

Mengetahui dan menganalisis kinerja keuangan pada PT Martina Berto Tbk dengan menggunakan rasio likuiditas, rasio solvabilitas, rasio aktivitas dan rasio profitabilitas.

\subsection{Perumusan Masalah}

1. Bagaimana kinerja keuangan PT Martina Berto Tbk ditinjau dari rasio likuiditas?

2. Bagaimana kinerja keuangan PT Martina Berto Tbk ditinjau dari rasio solvabilitas?

3. Bagaimana kinerja keuangan PT Martina Berto Tbk ditinjau dari rasio aktivitas?

4. Bagaimana kinerja keuangan PT Martina Berto Tbk ditinjau dari rasio profitabilitas?

\subsection{Tujuan Penelitian}

1. Mengetahui kinerja keuangan PT Martina Berto Tbk dalam memenuhi kewajiban jangka pendeknya menggunakan rasio likuiditas.

2. Mengetahui kinerja keuangan PT Martina Berto Tbk dalam mengelola utangnya untuk mendapatkan keuntungan dan juga mampu untuk melunasi kembali utangnya dengan menggunakan rasio solvabilitas.

3. Mengetahui kinerja keuangan PT Martina Berto Tbk untuk mengukur efektivitas perusahaan dalam menggunakan aset yang dimilikinya, efisiensi perusahaan serta pemanfaatan sumber daya dengan menggunakan rasio aktivitas.

4. Mengetahui kinerja keuangan PT Martina Berto Tbk dalam menghasilkan keuntungan dengan menggunakan rasio profitablitas.

\section{TINJAUAN PUSTAKA}

\subsection{Landasan Teori}

\section{Laporan Keuangan}

Menurut SAK No. 1 (2018:3), laporan keuangan adalah suatu penyajian terstruktur dari posisi keuangan dan kinerja keuangan suatu entitas.

Sedangkan menurut Kasmir (2015:7), laporan keuangan adalah laporan yang menunjukkan kondisi keuangan perusahaan pada saat ini atau dalam suatu periode tertentu.

\section{Jenis Laporan Keuangan}

Jenis laporan keuangan menurut Standar Akuntansi Keuangan (SAK) No. 1 (2018:3) laporan keuanganyang lengkap terdiri dari laporan posisi keuangan pada akhir periode; laporan laba rugi dan penghasilan komprehensif lain selama periode; laporan perubahan ekuitas selama periode; laporan arus kas selama periode; dan catatan atas laporan keuangan, berisi ringkasan kebijakan akuntansi yang signifikan dan informasi penjelasan lain.

\section{Pengertian Analisis Laporan Keuangan}

Menurut Hery (2016 : 113), analisis laporan keuangan merupakan suatu proses untuk membedah laporan keuangan ke dalam unsur-unsurnya dan menelaah masing-masing dari unsur tersebut dengan tujuan untuk memperoleh pengertian dan pemahaman yang baik dan tepat atas laporan keuangan itu sendiri. Analisis laporan keuangan merupakan suatu metode yang membantu para pengambil keputusan untuk mengetahui kekuatan dan kelemahan perusahaan melalui informasi yang didapat dari laporan keuangan. 


\section{Rasio Keuangan}

Menurut Kasmir (2015:104), rasio keuangan merupakan kegiatan memban-dingkan angkaangka yang ada dalam laporan keuangan dengan cara membagi satu angka dengan angka lainnya.

Menurut Hery (2016:140), analisis rasio keuangan adalah analisis yang digunakan dengan menghubungkan berbagai perkiraan yang ada pada laporan keuangan dalam bentuk laporan keuangan dengan rasio keuangan.

\section{Kinerja Keuangan}

Menurut Fahmi (2017:238), kinerja keuangan adalah suatu analisis yang dilakukan untuk melihat sejauh mana suatu perusahaan telah melaksanakan dengan menggunakan aturan-aturan pelaksanaan keuangan secara baik dan benar. Seperti dengan membuat membuat suatu laporan keuangan yang telah memenuhi dan ketentuan dalam SAK (Standar Akuntansi Keuangan) atau GGAP (General Acepted Accounting Principle), dan lainnya.

\section{Hubungan Rasio Keuangan dan Kinerja Keuangan}

Menurut Warsidi dan Bambang dalam Fahmi (2017:108), analisis rasio keuangan merupakan instrumen prestasi perusahaan yang menjelaskan berbagai hubungan dan indikator keuangan yang ditunjukan untuk menunjukan perubahan dalam kondisi keuangan atau prestasi operasi dimasa lalu dan membantu menggambarkan trend perubahan tersebut, untuk kemudian menunjukan risiko dan peluang yang melekat pada perusahaan yang bersangkutan.

\subsection{Kerangka Pemikiran}

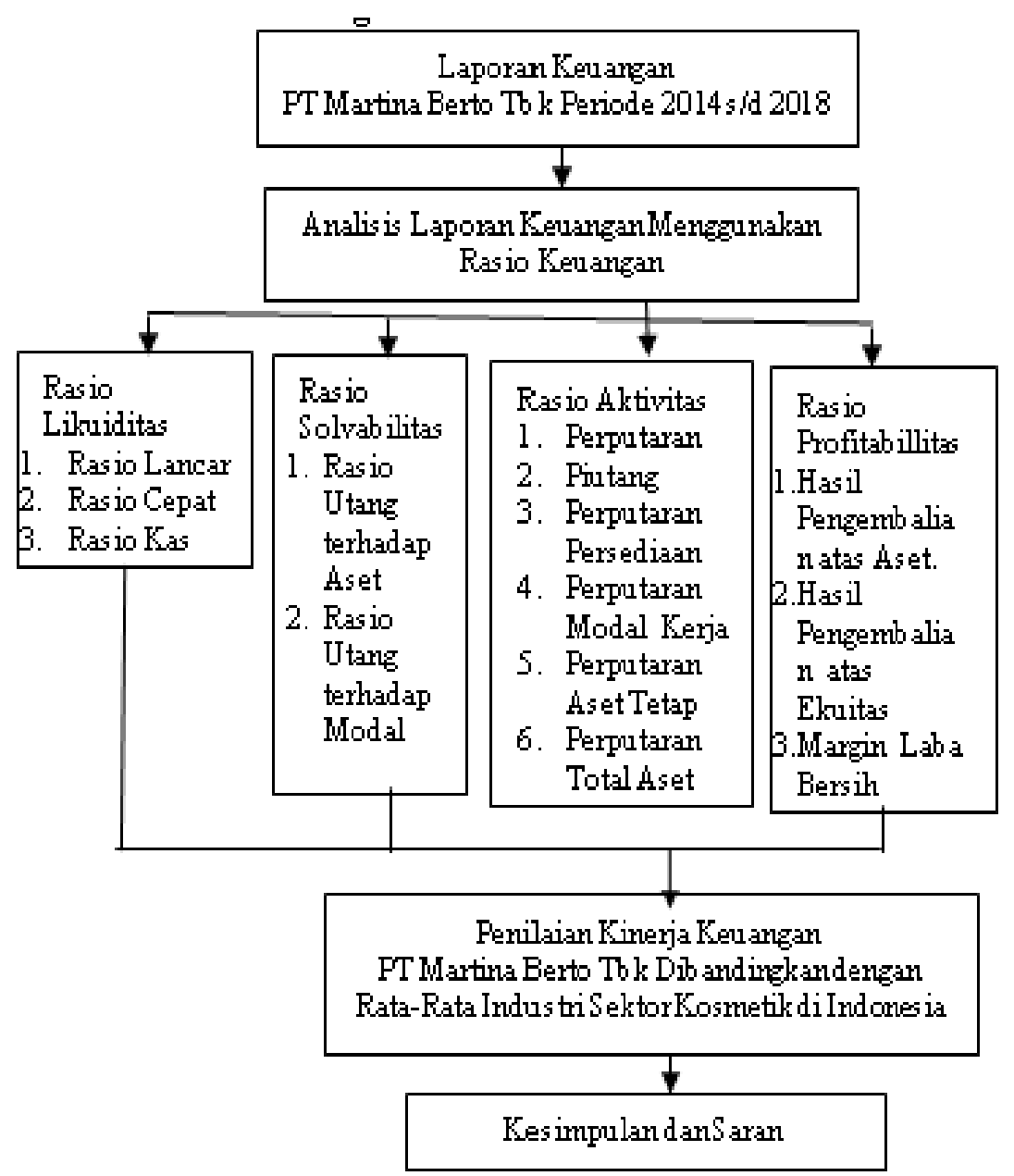

Gambar 2. Skema Kerangka Pemikiran 


\section{METODOLOGI PENELITIAN}

\subsection{Jenis Penelitian}

Penelitian yang dilakukan adalah dengan menggunakan pendekatan kuanti-tatif dengan jenis penelitian ini adalah penelitian deskriptif.

\subsection{Lokasi dan Waktu Penelitian}

Penelitian ini dilakukan dengan data sekunder yang berupa laporan keuangan tahunan PT Martina Berto Tbk dengan mengakses situs resmi perusahaan PT Martina Berto Tbk yaitu www.martinaberto.co.id dan situs resmi Bursa Efek Indonesia yaitu www.idx.co.id pada tanggal 15-18 Juli 2019. Waktu penelitian ini dilakukan selama 6 bulan yakni dimulai pada bulan September 2019 hingga Maret 2020

\subsection{Populasi dan Sampel}

\section{Populasi}

Dalam penelitian ini adalah seluruh data laporan keuangan tahunan PT Martina Berto Tbk yang tercatat di situs resmi PT Martina Berto Tbk dan Bursa Efek Indonesia.

\section{Sampel}

Dalam penelitian ini sampelnya adalah data laporan keuangan tahunan PT Martina Berto Tbk periode 2014-2018, dengan tujuan mampu memberikan informasi kinerja keuangan terkini dari perusahaan PT Martina Berto Tbk.

\subsection{Teknik Pengumpulan Data}

\section{Sumber Sekunder}

Penulis mendapatkan data dan informasi melalui situs resmi PT Martina Berto Tbk www.martinaberto.co.id. dan situs resmi Bursa Efek Indonesia yaitu www.idx.co.id.

\section{Penilaian Kepustakaan}

Dengan mengumpulkan data-data serta informasi bahan yang berhubungan erat dengan judul penelitian guna melengkapi data yang sudah ada melalui buku-buku, literatur, bahan-bahan dan catatan kuliah serta dokumen-dokumen lainnya yang berhubungan dengan peneliti.

\subsection{Teknik Analisis Data}

\section{A. Analisis Rasio Keuangan}

\section{Rasio Likuiditas}

a. Rasio Lancar (Current Ratio)

Current Ratio $=\frac{\text { Aset lancar }}{\text { Liabilitas lancar }} \times 100 \%$

b. Rasio Sangat Lancar atau Rasio Cepat (Quick Ratio atau Acid Test Ratio)

QuickRatio $=\frac{\text { Aset lancar }- \text { persediaan }}{\text { Liabilitas lancar }} \times 100 \%$

c. Rasio Kas (Cash Ratio)

CashRatio $=\frac{\text { Kas dan setara kas }}{\text { Liabilitas lancar }} \times 100 \%$

\section{Rasio Solvabilitas}

a. Rasio Utang Terhadap Aset(Debt to Assets Ratio)

Debt to Asset Ratio $=\frac{\text { Total liabilitas }}{\text { Total aset }} \times 100 \%$

b. Rasio Utang terhadap Modal (Debt to Equity Ratio) 
Debt to Equity Ratio $=\frac{\text { Total liabilitas }}{\text { Total ekuitas }} \times 100 \%$

\section{Rasio Aktivitas}

a. Perputaran Piutang (Receivable Turn Over)

$$
\text { Rasio perputaran piutang }=\frac{\text { Penjualan }}{\text { Piutang }}
$$

b. Perputaran Persediaan (Inventory Turn Over)

$$
\text { Rasio perputaran persediaan }=\frac{\text { Penjualan }}{\text { Persediaan }}
$$

c. Perputaran Modal Kerja (Working Capital Turn Over)

$$
\text { Rasio perputaran modal kerja }=\frac{\text { Penjualan }}{\text { Total aset lancar }}
$$

d. Perputaran Aset Tetap (Fixed Assets Turn Over)

e. Perputaran Total Aset (Total Assets Turn Over)

$$
\text { Rasio perputaran aset tetap }=\frac{\text { Penjualan }}{\text { Aset tetap }}
$$

$$
\text { Rasio perputaran total aset }=\frac{\text { Penjualan }}{\text { Total aset }}
$$

\section{Rasio Profitabilitas}

a. Hasil Pengembalian atas Aset (Return on Assets)

Return on Assets $=\frac{\text { Laba bersih }}{\text { Total aset }} \times 100 \%$

b. Hasil Pengembalian atas Ekuitas (Return on Equity)

Return On Equity $=\frac{\text { Laba bersih }}{\text { Total ekuitas }} \times 100 \%$

c. Margin Laba Bersih (Net Profit Margin)

Net Profit Margin $=\frac{\text { Laba bersih }}{\text { Penjualan bersih }} \times 100 \%$

B. Menginterpretasikan dan membanding-kan hasil pengukuran rasio-rasio keuangan dengan rata-rata industri

\section{HASIL DAN PEMBAHASAN}

\section{Hasil Perhitungan dan Pembahasan Rasio Keuangan PT Martina Berto Tbk}

Peneliti menggunakan rata-rata industri dengan menghitung dari empat perusahaan sejenis dengan periode yang sama untuk memperoleh standar standar umum sebagai pengukur kinerja keuangan perusahaan.

Tabel 2. Rata-Rata Industri Empat Perusahaan Kosmetik di Indonesia (PT Martina Berto Tbk, PT Mustika Ratu Tbk, PT Mandom IndonesiaTbk dan PT Kino Indonesia Tbk Periode 2014-2018) 


\begin{tabular}{|c|c|c|c|c|c|}
\hline \multirow[t]{2}{*}{ Rasio } & \multicolumn{5}{|c|}{$\begin{array}{l}\text { Rata-rata Industri Empat Perusahaan Kosmetik } \\
\text { di Indonesia }\end{array}$} \\
\hline & 2014 & 2015 & 2016 & 2017 & 2018 \\
\hline Rasio Lancar & $312,17 \%$ & $336,22 \%$ & $345,37 \%$ & $305,59 \%$ & $306,95 \%$ \\
\hline Rasio Cepat & $233,39 \%$ & $254,59 \%$ & $242,40 \%$ & $220,22 \%$ & $199,51 \%$ \\
\hline Rasio Kas & $30,36 \%$ & $51,53 \%$ & $48,69 \%$ & $55,46 \%$ & $48,37 \%$ \\
\hline $\begin{array}{l}\text { Rasio Utang } \\
\text { terhadap Aset }\end{array}$ & $26,84 \%$ & $29,89 \%$ & $30,11 \%$ & $32,81 \%$ & $35,05 \%$ \\
\hline $\begin{array}{l}\text { Rasio Utang } \\
\text { terhadap } \\
\text { Ekuitas }\end{array}$ & $36,93 \%$ & $45,86 \%$ & $45,67 \%$ & $52,35 \%$ & $60,74 \%$ \\
\hline $\begin{array}{l}\text { Perputaran } \\
\text { Piutang }\end{array}$ & 3,78 kali & 3,11 kali & 3,56 kali & 3,43 kali & 3,44 kali \\
\hline $\begin{array}{l}\text { Perputaran } \\
\text { Persediaan }\end{array}$ & 6,49 kali & 7,76 kali & 6,18 kali & 6,21 kali & 4,74 kali \\
\hline $\begin{array}{l}\text { Perputaran } \\
\text { Modal Kerja }\end{array}$ & 1,77 kali & 1,60 kali & 1,60 kali & 1,55 kali & 1,47 kali \\
\hline $\begin{array}{l}\text { Perputaran } \\
\text { Aset Tetap }\end{array}$ & 2,49 kali & 2,85 kali & 2,65 kali & 2,63 kali & 2,31 kali \\
\hline $\begin{array}{l}\text { Perputaran } \\
\text { Total Aset }\end{array}$ & 1,27 kali & 1,24 kali & 1,22 kali & 1,22 kali & 1,24 kali \\
\hline $\begin{array}{l}\text { Hasil } \\
\text { Pengembalian } \\
\text { atas Aset }\end{array}$ & $3,79 \%$ & $8,10 \%$ & $3,26 \%$ & $1,89 \%$ & $-1,70 \%$ \\
\hline $\begin{array}{l}\text { Hasil } \\
\text { Pengembalian } \\
\text { atas Ekuitas }\end{array}$ & $5,38 \%$ & $10,90 \%$ & $4,72 \%$ & $2,16 \%$ & $-5,74 \%$ \\
\hline $\begin{array}{l}\text { Margin Laba } \\
\text { Bersih }\end{array}$ & $3,23 \%$ & $7,26 \%$ & $2,82 \%$ & $1,59 \%$ & $-3,19 \%$ \\
\hline
\end{tabular}

Sumber : Data diolah peneliti, 2019

\section{Rasio Likuditias}

\section{1) Rasio Lancar (Current Ratio)}

Tabel 3. Hasil Perhitungan Rasio Rasio Lancar PT Martina Berto Tbk Periode 2014-2018 (Dalam Rupiah)

\begin{tabular}{ccccc}
\hline Tahun & $\begin{array}{c}\text { Aset Lancar } \\
\text { (Rupiah) }\end{array}$ & $\begin{array}{c}\text { Liabilitas Lancar } \\
\text { (Rupiah) }\end{array}$ & $\begin{array}{c}\text { Rasio } \\
\text { Lancar (\%) }\end{array}$ & $\begin{array}{c}\text { Rata-Rata } \\
\text { Industri } \\
(\%)\end{array}$ \\
\hline 2014 & 441.621 .631 .299 & 111.683 .722 .179 & $395,42 \%$ & $312,17 \%$ \\
2015 & 467.304 .062 .732 & 149.060 .988 .246 & $313,50 \%$ & $336,22 \%$ \\
2016 & 472.762 .014 .033 & 155.284 .557 .576 & $304,45 \%$ & $345,37 \%$ \\
2017 & 520.384 .083 .342 & 252.247 .858 .307 & $206,30 \%$ & $305,59 \%$ \\
2018 & 392.357 .840 .917 & 240.203 .560 .883 & $163,34 \%$ & $306,95 \%$ \\
\hline
\end{tabular}

Sumber : Data diolah peneliti, 2019

Rasio lancar pada tahun 2014 sebesar 395,42\% artinya setiap Rp100,00 liabilitas lancar dijamin oleh Rp395,42 aset lancar. Pada tahun 2015 sebesar 313,50\% artinya setiap Rp100,00 liabilitas lancar dijamin oleh Rp313,50 aset lancar. Pada tahun 2016 sebesar 304,45\%, artinya setiap Rp100,00 liabilitas lancar dijamin oleh Rp304,45 aset lancar. Pada tahun 2017 sebesar 206,30\%, artinya setiap Rp100,00 liabilitas lancar dijamin oleh Rp206,30 aset lancar. Pada tahun 2018 sebesar 163,34\%, artinya setiap Rp100,00 liabilitas lancar dijamin oleh Rp163,34 aset lancar. Berdasarkan analisis rasio lancar (current ratio), jika dilihat dari presentasenya kinerja terbaik terjadi pada tahun 2014 yaitu sebesar 395,42\% yang melebihi rata-rata industri yaitu sebesar $312,17 \%$, namun kinerja rasio lancar PT Martina Berto Tbk yang diperoleh selama tahun 2015- 
2018 dapat disimpulkan cenderung kurang baik jika dibandingkan dengan perusahaan sejenis lainnya karena nilai rasionya masih dibawah rata-rata industri.

\section{2) Rasio Sangat Lancar atau Rasio Cepat (Quick Ratio atau Acid Test Ratio)}

Tabel 4. Hasil Perhitungan Rasio Sangat Lancar/Rasio Cepat PT Martina Berto Tbk Periode 2014-2018 (Dalam Rupiah)

\begin{tabular}{lccccc}
\hline Tahun & $\begin{array}{c}\text { Aset Lancar } \\
\text { (Rupiah) }\end{array}$ & $\begin{array}{c}\text { Persediaan } \\
\text { (Rupiah) }\end{array}$ & $\begin{array}{c}\text { Liabilitas } \\
\text { Lancar (Rupiah) }\end{array}$ & $\begin{array}{c}\text { Rasio } \\
\text { Cepat } \\
(\%)\end{array}$ & $\begin{array}{c}\text { Rata-Rata } \\
\text { Industri } \\
(\%)\end{array}$ \\
\hline 2014 & 441.621 .631 .299 & 74.985 .171 .053 & 111.683 .722 .179 & $328,28 \%$ & $233,39 \%$ \\
2015 & 467.304 .062 .732 & 76.682 .141 .187 & 149.060 .988 .246 & $262,06 \%$ & $254,59 \%$ \\
2016 & 472.762 .014 .033 & 94.201 .581 .437 & 155.284 .557 .576 & $243,78 \%$ & $242,40 \%$ \\
2017 & 520.384 .083 .342 & 103.446 .614 .309 & 252.247 .858 .307 & $165,29 \%$ & $220,22 \%$ \\
2018 & 392.357 .840 .917 & 106.276 .782 .334 & 240.203 .560 .883 & $119,10 \%$ & $199,51 \%$ \\
\hline
\end{tabular}

Sumber : Data diolah Peneliti,2019

Rasio cepat pada tahun 2014 sebesar 328,28\%, artinya setiap Rp100,00 liabilitas lancar dijamin oleh Rp328,28 aset sangat lancar. Pada tahun 2015 sebesar 262,06\%, artinya setiap Rp100,00 liabilitas lancar dijamin oleh Rp262,06 aset sangat lancar. Pada tahun 2016 sebesar 243,78\%, artinya setiap Rp100,00 liabilitas lancar dijamin oleh Rp243,78 aset sangat lancar. Pada tahun 2017 sebesar 165,29\%, artinya setiap Rp100,00 liabilitas lancar dijamin oleh Rp165,29 aset sangat lancar. Pada tahun 2018 sebesar 119,10\%, artinya setiap Rp100,00 liabilitas lancar dijamin dijamin 119,10 aset sangat lancar. Berdasarkan analisis rasio cepat (quick ratio), jika dilihat dari presentasenya kinerja rasio cepat pada tahun 2014-2016 dapat disimpulkan lebih baik jika dibandingkan dengan perusahaan sejenis lainnya karena nilai rasionya berada diatas rata-rata industri. Namun, pada tahun 2017-2018 kinerja rasio cepat cenderung kurang baik jika dibandingkan dengan perusahaan sejenis karena nilai rasionya masih dibawah rata-rata industri.

\section{3) Rasio Kas (Cash Ratio)}

Tabel 5. Hasil Perhitungan Rasio Kas PT Martina Berto Tbk Periode 2014-2018 (Dalam Rupiah)

\begin{tabular}{ccccc}
\hline Tahun & $\begin{array}{c}\text { Kas dan Setara } \\
\text { Kas (Rupiah) }\end{array}$ & $\begin{array}{c}\text { Liabilitas } \\
\text { Lancar (Rupiah) }\end{array}$ & $\begin{array}{c}\text { Rasio } \\
\text { Kas (\%) }\end{array}$ & $\begin{array}{c}\text { Rata- } \\
\text { Rata } \\
\text { Industri } \\
(\%)\end{array}$ \\
\hline 2014 & 41.256 .538 .369 & 111.683 .722 .179 & $36,94 \%$ & $30,36 \%$ \\
2015 & 30.922 .884 .864 & 149.060 .988 .246 & $20,75 \%$ & $51,53 \%$ \\
2016 & 6.593 .262 .476 & 155.284 .557 .576 & $4,25 \%$ & $48,69 \%$ \\
2017 & 5.238 .550 .050 & 252.247 .858 .307 & $2,08 \%$ & $55,46 \%$ \\
2018 & 3.998 .894 .576 & 240.203 .560 .883 & $1,66 \%$ & $48,37 \%$ \\
\hline
\end{tabular}

Sumber : Data diolah Peneliti,2019

Rasio kas pada tahun 2014 sebesar 36,94\%, artinya setiap Rp100,00 liabilitas lancar dijamin oleh Rp36,94 kas. Pada tahun 2015 sebesar 20,75\%, artinya setiap Rp100,00 liabilitas lancar dijamin oleh Rp20,75 kas. Pada tahun 2016 sebesar 4,25\%, artinya setiap Rp100,00 liabilitas lancar dijamin oleh Rp4,25 kas. Pada tahun 2017 sebesar 2,08\%, artinya setiap Rp100,00 liabilitas lancar dijamin oleh Rp2,08 kas. Pada tahun 2018 sebesar 1,66\%, artinya setiap Rp100,00 liabilitas lancar dijamin oleh Rp1,66 kas. Berdasarkan analisis rasio kas (cash ratio), jika dilihat dari presentasenya kinerja terbaik terjadi pada tahun 2014 yaitu sebesar 36,94\% melebihi rata-rata industri perusahaan sejenis yaitu sebesar 30,36\%. Kinerja rasio kas pada tahun 2015-2018 mengalami penurunan disetiap tahunnya dan dapat disimpulkan cenderung kurang baik jika dibandingkan dengan perusahaan sejenis lainnya karena nilai rasionya masih dibawah rata-rata industri. 


\section{Rasio Solvabilitas}

\section{1) Rasio Utang terhadap Aset (Debt to Assets Ratio)}

Tabel 6. Hasil Perhitungan Rasio Utang terhadap Aset PT Martina Berto Tbk Periode 2014-2018 (Dalam Rupiah)

\begin{tabular}{ccccc}
\hline Tahun & $\begin{array}{c}\text { Total Liabilitas } \\
\text { (Rupiah) }\end{array}$ & $\begin{array}{c}\text { Total Aset } \\
\text { (Rupiah) }\end{array}$ & $\begin{array}{c}\text { Rasio } \\
\text { Utang } \\
\text { terhadap } \\
\text { Aset } \\
(\%)\end{array}$ & $\begin{array}{c}\text { Rata- } \\
\text { Rata } \\
\text { Industri } \\
(\%)\end{array}$ \\
\hline 2014 & 165.633 .948 .162 & 619.383 .082 .066 & $26,74 \%$ & $26,84 \%$ \\
2015 & 214.685 .781 .274 & 648.899 .377 .240 & $33,08 \%$ & $29,89 \%$ \\
2016 & 269.032 .270 .377 & 709.959 .168 .088 & $37,89 \%$ & $30,11 \%$ \\
2017 & 367.927 .139 .244 & 780.669 .761 .787 & $47,13 \%$ & $32,81 \%$ \\
2018 & 347.517 .123 .452 & 648.016 .880 .325 & $53,63 \%$ & $35,05 \%$ \\
\hline \multicolumn{5}{c}{ Sumber : Data diolah Peneliti,2019 }
\end{tabular}

Rasio utang terhadap aset pada tahun 2014 sebesar 26,74\%, artinya setiap Rp100,00 aset dibiayai oleh Rp26,74 utang dan Rp73,26 oleh modal. Pada tahun 2015 sebesar 33,08\%, artinya setiap Rp100,00 aset dibiayai oleh Rp33,08 utang dan Rp66,92 oleh modal. Pada tahun 2016 sebesar 37,89\%, artinya setiap Rp100,00 aset dibiayai oleh Rp37,89 utang dan Rp62,11 oleh modal. Pada tahun 2017 sebesar 47,13\%, artinya setiap Rp100,00 aset dibiayai oleh Rp47,13 utang dan Rp52,87 oleh modal. Pada tahun 2018 sebesar 53,63\%, artinya setiap Rp100,00 aset dibiayai oleh Rp53,63 utang dan Rp46,37\% oleh modal. Berdasarkan analisis rasio utang terhadap aset (debt to asset ratio), jika dilihat dari presentasenya kinerja terbaik terjadi pada tahun 2014 yaitu sebesar 26,74\% karena memiliki nilai terendah dan masih dibawah rata-rata industri yaitu sebesar 26,84\%. Kinerja rasio utang terhadap aset PT Martina Berto Tbk pada tahun 2015-2018 mengalami kenaikan disetiap tahunnya dan melebihi rata-rata industri sehingga dapat disimpulkan cenderung kurang baik jika dibandingkan dengan perusahaan sejenis lainnya. Apabila besaran rasio utang terhadap aset adalah tinggi maka hal ini memberikan risiko kredit yang tinggi karena pendanaan aset dengan liabilitas yang lebih besar.

\section{2) Rasio Utang terhadap Modal (Debt to Equity Ratio)}

Tabel 7. Hasil Perhitungan Rasio Utang terhadap Modal PT Martina Berto Tbk Periode 2014-2018 (Dalam Rupiah)

\begin{tabular}{ccccc}
\hline Tahun & $\begin{array}{c}\text { Total Liabilitas } \\
\text { (Rupiah) }\end{array}$ & $\begin{array}{c}\text { Total Ekuitas } \\
\text { (Rupiah) }\end{array}$ & $\begin{array}{c}\text { Rasio } \\
\text { Utang } \\
\text { terhadap } \\
\text { Modal } \\
(\%)\end{array}$ & $\begin{array}{c}\text { Rata- } \\
\text { Rata } \\
\text { Industri } \\
(\%)\end{array}$ \\
\hline 2014 & 165.633 .948 .162 & 453.749 .133 .904 & $36,50 \%$ & $36,93 \%$ \\
2015 & 214.685 .781 .274 & 434.213 .595 .966 & $49,44 \%$ & $45,86 \%$ \\
2016 & 269.032 .270 .377 & 440.926 .897 .711 & $61,02 \%$ & $45,67 \%$ \\
2017 & 367.927 .139 .244 & 412.742 .622 .543 & $89,14 \%$ & $52,35 \%$ \\
2018 & 347.517 .123 .452 & 300.499 .756 .873 & $115,65 \%$ & $60,74 \%$ \\
\hline
\end{tabular}

Sumber : Data diolah Peneliti,2019

Rasio utang terhadap modal pada tahun 2014 sebesar 36,50\%, artinya setiap Rp36,50 utang hanya dijamin oleh Rp100,00 modal. Pada tahun 2015 sebesar 49,44\%, artinya setiap Rp49,44 utang hanya dijamin oleh Rp100,00 modal. Pada tahun 2016 sebesar 61,02\%, artinya setiap Rp61,02 utang hanya dijamin oleh Rp100,00 modal. Pada tahun 2017 sebesar 89,14\%, artinya setiap Rp89,14 utang hanya dijamin oleh Rp100,00 modal. Pada tahun 2018 sebesar 115,65\%, artinya setiap Rp115,65 utang hanya dijamin oleh Rp100,00 modal. Berdasarkan analisis rasio 
utang terhadap modal (debt to equity ratio), jika dilihat dari presentasenya kinerja terbaik terjadi pada tahun 2014 yaitu sebesar 36,50\% karena masih dibawah rata-rata industri perusahaan sejenis yaitu sebesar 36,93\%. Kinerja rasio utang terhadap modal pada tahun 2015-2018 cenderung kurang baik jika dibandingkan dengan perusahaan sejenis lainnya karena besar rasionya masih diatas ratarata industri. Semakin tinggi rasio utang terhadap modal maka semakin kecil jumlah modal yang dijadikan sebagai jaminan utang sehingga menimbulkan konsekuensi bagi kreditor untuk menanggung risiko yang lebih besar pada saat debitur mengalami kegagalan keuangan.

\section{Rasio Aktivitas}

\section{1) Perputaran Piutang (Receivable Turn Over)}

Tabel 8. Hasil Perhitungan Rasio Perputaran Piutang PT Martina Berto Tbk Periode 2014-2018 (Dalam Rupiah)

\begin{tabular}{ccccc}
\hline Tahun & $\begin{array}{c}\text { Penjualan } \\
\text { (Rupiah) }\end{array}$ & $\begin{array}{c}\text { Piutang } \\
\text { (Rupiah) }\end{array}$ & $\begin{array}{c}\text { Perputaran } \\
\text { Piutang } \\
\text { (Kali) }\end{array}$ & $\begin{array}{c}\text { Rata- } \\
\text { Rata } \\
\text { Industri } \\
\text { (Kali) }\end{array}$ \\
\hline 2014 & 671.398 .849 .823 & 303.320 .568 .986 & 2,21 & 3,78 \\
2015 & 694.782 .752 .351 & 337.082 .565 .169 & 2,06 & 3,11 \\
2016 & 685.443 .920 .925 & 347.374 .813 .632 & 1,97 & 3,56 \\
2017 & 731.577 .343 .628 & 389.111 .590 .600 & 1,88 & 3,43 \\
2018 & 502.517 .714 .607 & 249.236 .546 .287 & 2,02 & 3,44 \\
\hline
\end{tabular}

Sumber : Data diolah Peneliti,2019

Rasio perputaran piutang pada tahun 2014 sebesar 2,21, artinya dalam satu tahun dana yang tertanam dalam piutang berputar sebanyak 2,21 kali. Pada tahun 2015 sebesar 2,06, artinya dalam satu tahun dana yang tertanam dalam piutang berputar sebanyak 2,06 kali. Pada tahun 2016 sebesar 1,97 , artinya dalam satu tahun dana yang tertanam dalam piutang berputar sebanyak 1,97 kali. Pada tahun 2017 sebesar 1,88, artinya dalam satu tahun dana yang tertanam dalam piutang berputar sebanyak 1,88 kali. Pada tahun 2018 sebesar 2,02, artinya dalam satu tahun dana yang tertanam dalam piutang berputar sebanyak 2,02 kali. Berdasarkan analisis, maka kinerja rasio perputaran piutang pada tahun 2014-2018 cenderung sedikit kurang baik jika dibandingkan dengan perusahaan sejenis lainnya karena besar rasionya berada dibawah rata-rata industri.

\section{2) Perputaran Persediaan (Inventory Turn Over)}

Tabel 9. Hasil Perhitungan Rasio Perputaran PT Martina Berto Tbk Periode 2014-2018 (Dalam Rupiah)

\begin{tabular}{ccccc}
\hline Tahun & $\begin{array}{c}\text { Penjualan } \\
\text { (Rupiah) }\end{array}$ & $\begin{array}{c}\text { Persediaan } \\
\text { (Rupiah) }\end{array}$ & $\begin{array}{c}\text { Perputaran } \\
\text { Persediaan } \\
\text { (Kali) }\end{array}$ & $\begin{array}{c}\text { Rata- } \\
\text { Rata } \\
\text { Industri } \\
\text { (Kali) }\end{array}$ \\
\hline 2014 & 671.398 .849 .823 & 74.985 .171 .053 & 8,95 & 6,49 \\
2015 & 694.782 .752 .351 & 76.682 .141 .187 & 9,06 & 7,76 \\
2016 & 685.443 .920 .925 & 94.201 .581 .437 & 7,28 & 6,18 \\
2017 & 731.577 .343 .628 & 103.446 .614 .309 & 7,07 & 6,21 \\
2018 & 502.517 .714 .607 & 106.276 .782 .334 & 4,73 & 4,74 \\
\hline
\end{tabular}

Sumber : Data diolah Peneliti,2019

Rasio perputaran persediaan pada tahun 2014 sebesar 8,95, artinya dalam satu tahun dana yang tertanam dalam persediaan berputar sebanyak 8,95 kali. Pada tahun 2015 sebesar 9,06, artinya dalam satu tahun dana yang tertanam dalam persediaan berputar sebanyak 9,06 kali. Pada tahun 2016 sebesar 7,28, artinya dalam satu tahun dana yang tertanam dalam persediaan berputar 
sebanyak 7,28 kali. Pada tahun 2017 sebesar 7,07, artinya dalam satu tahun dana yang tertanam dalam persediaan berputar sebanyak 7,07 kali. Pada tahun 2018 sebesar 4,73, artinya dalam satu tahun dana yang tertanam dalam persediaan berputar sebanyak 4,73 kali. Berdasarkan analisis rasio perputaran persediaan, kinerja terbaik terjadi pada tahun 2015 sebesar 9,06 kali sehingga memiliki nilai tertinggi dan berada diatas rata-rata industri perusahaan sejenis. Kinerja terbaik lainnya terjadi pada tahun 2014, 2016 dan 2017 meskipun mengalami penurunan disetiap tahunnya, namun masih berada diatas rata-rata industri. Rasio perputaran persediaan pada tahun 2018 sebesar 4,73 kali masih dibawah rata-rata standar industri sebesar 4,74 kali dan dikatergorikan cenderung sedikit kurang baik.

\section{3) Perputaran Modal Kerja (Working Capital Turn Over)}

Tabel 10. Hasil Perhitungan Rasio Perputaran Modal Kerja PT Martina Berto Tbk Periode 2014-2018 (Dalam Rupiah)

\begin{tabular}{ccccc}
\hline Tahun & $\begin{array}{c}\text { Penjualan } \\
\text { (Rupiah) }\end{array}$ & $\begin{array}{c}\text { Aset Lancar } \\
\text { (Rupiah) }\end{array}$ & $\begin{array}{c}\text { Perputaran } \\
\text { Modal } \\
\text { Kerja } \\
\text { (Kali) }\end{array}$ & $\begin{array}{c}\text { Rata- } \\
\text { Rata } \\
\text { Industri } \\
\text { (Kali) }\end{array}$ \\
\hline 2014 & 671.398 .849 .823 & 441.621 .631 .299 & 1,52 & 1,77 \\
2015 & 694.782 .752 .351 & 467.304 .062 .732 & 1,49 & 1,60 \\
2016 & 685.443 .920 .925 & 472.762 .014 .033 & 1,45 & 1,60 \\
2017 & 731.577 .343 .628 & 520.384 .083 .342 & 1,41 & 1,55 \\
2018 & 502.517 .714 .607 & 392.357 .840 .917 & 1,28 & 1,47 \\
\hline
\end{tabular}

Sumber : Data diolah Peneliti,2019

Rasio perputaran modal kerja pada tahun 2014 sebesar 1,52, setiap Rp1,00 aset lancar turut berkontribusi mencip-takan Rp1,52 penjualan .Rasio perputaran persediaan pada tahun 2015 sebesar 1,49, artinya setiap Rp1,00 aset lancar turut berkontribusi menciptakan Rp1,49 penjualan. Pada tahun 2016 sebesar 1,45, artinya setiap Rp1,00 aset lancar turut berkontribusi menciptakan Rp1,45 penjualan. Pada tahun 2017 sebesar 1,41, artinya setiap Rp1,00 aset lancar turut berkontribusi menciptakan Rp1,41 penjualan. Pada tahun 2018 sebesar 1,28, artinya setiap Rp1,00 aset lancar turut berkontribusi menciptakan Rp1,28 penjualan. Berdasarkan analisis rasio perputaran modal kerja, rasio perputaran modal kerja PT Martina Berto Tbk selama tahun 20142018 cenderung sedikit kurang baik jika dibandingkan dengan perusahaan sejenis lainnya karena nilai rasionya masih dibawah rata-rata industri.

\section{4) Perputaran Aset Tetap (Fixed Assets Turn Over)}

Tabel 11. Hasil Perhitungan Rasio Perputaran Modal Aset Tetap PT Martina Berto Tbk Periode 2014-2018 (Dalam Rupiah)

\begin{tabular}{ccccc} 
Tahun & $\begin{array}{c}\text { Penjualan } \\
\text { (Rupiah) }\end{array}$ & $\begin{array}{c}\text { Aset Tetap } \\
\text { (Rupiah) }\end{array}$ & $\begin{array}{c}\text { Perputaran } \\
\text { Aset } \\
\text { Tetap } \\
\text { (Kali) }\end{array}$ & $\begin{array}{c}\text { Rata- } \\
\text { Rata } \\
\text { Industri } \\
\text { (Kali) }\end{array}$ \\
\hline 2014 & 671.398 .849 .823 & 148.954 .451 .135 & 4,51 & 2,49 \\
2015 & 694.782 .752 .351 & 145.278 .949 .208 & 4,78 & 2,85 \\
2016 & 685.443 .920 .925 & 146.765 .140 .999 & 4,67 & 2,65 \\
2017 & 731.577 .343 .628 & 151.096 .093 .283 & 4,84 & 2,63 \\
2018 & 502.517 .714 .607 & 134.332 .773 .420 & 3,74 & 2,31 \\
\hline
\end{tabular}

Sumber : Data diolah Peneliti,2019

Rasio perputaran aset tetap pada tahun 2014 sebesar 4,51, artinya setiap Rp1,00 aset tetap turut berkontribusi menciptakan Rp4,51 penjualan. Pada tahun 2015 sebesar 4,78, artinya setiap Rp1,00 aset tetap turut berkontribusi menciptakan Rp4,78 penjualan. Pada tahun 2016 sebesar 4,67, artinya setiap Rp1,00 aset tetap turut berkontribusi menciptakan Rp4,67 penjualan. Pada tahun 
2017 sebesar 4,84, artinya setiap Rp1,00 aset tetap turut berkontribusi menciptakan Rp4,84 penjualan. Pada tahun 2018 sebesar 3,74, artinya setiap Rp1,00 aset tetap turut berkontribusi menciptakan Rp3,74 penjualan. Berdasar-kan analisis rasio perputaran aset tetap, kinerja terbaik terjadi pada tahun 2017 sebesar 4,84 kali sehingga memiliki nilai tertinggi dan berada diatas ratarata industri perusahaan sejenis. Sehingga dapat disimpulkan, meskipun terjadi fluktuasi, rasio perputaran aset tetap pada tahun 2014-2018 PT cenderung lebih baik jika dibandingkan dengan perusahaan sejenis lainnya karena nilai rasionya berada diatas rata-rata industri.

\section{5) Perputaran Total Aset ( Total Assets Turn Over)}

Tabel 12. Hasil Perhitungan Rasio Perputaran Total Aset PT Martina Berto Tbk Periode 2014-2018 (Dalam Rupiah)

\begin{tabular}{ccccc}
\hline Tahun & $\begin{array}{c}\text { Penjualan } \\
\text { (Rupiah) }\end{array}$ & $\begin{array}{c}\text { Total Aset } \\
\text { (Rupiah) }\end{array}$ & $\begin{array}{c}\text { Perputaran } \\
\text { Total Aset } \\
\text { (Kali) }\end{array}$ & $\begin{array}{c}\text { Rata- } \\
\text { Rata } \\
\text { Industri } \\
\text { (Kali) }\end{array}$ \\
\hline 2014 & 671.398 .849 .823 & 619.383 .082 .066 & 1,08 & 1,27 \\
2015 & 694.782 .752 .351 & 648.899 .377 .240 & 1,07 & 1,24 \\
2016 & 685.443 .920 .925 & 709.959 .168 .088 & 0,97 & 1,22 \\
2017 & 731.577 .343 .628 & 780.669 .761 .787 & 0,94 & 1,22 \\
2018 & 502.517 .714 .607 & 648.016 .880 .325 & 0,78 & 1,24 \\
\hline
\end{tabular}

Sumber : Data diolah Peneliti,2019

Rasio perputaran total aset pada tahun 2014 sebesar 1,08, artinya setiap Rp1,00 total aset turut berkontribusi menciptakan Rp1,08 penjualan. Pada tahun 2015 sebesar 1,07, artinya setiap Rp1,00 total aset turut berkontribusi menciptakan Rp1,07 penjualan. Pada tahun 2016 sebesar 0,97, artinya setiap Rp1,00 total aset turut berkontribusi menciptakan Rp0,97 penjualan. Pada tahun 2017 sebesar 0,94, artinya setiap Rp1,00 total aset turut berkontribusi menciptakan Rp0,94 penjualan. Pada tahun 2018 sebesar 0,78, artinya setiap Rp1,00 total aset turut berkontribusi menciptakan Rp0,78 penjualan. Berdasar-kan analisis, kinerja rasio perputaran total aset selama tahun 20142018 cenderung sedikit kurang baik jika dibandingkan dengan perusahaan sejenis lainnya karena nilai rasionya masih dibawah rata-rata industri.

\section{Rasio Profitabilitas}

\section{1) Hasil Pengembalian atas Aset (Return on Assets)}

Tabel 13. Hasil Perhitungan Rasio Hasil Pengembalian atas Aset PT Martina Berto Tbk Periode 2014-2018 (Dalam Rupiah)

\begin{tabular}{ccccc}
\hline Tahun & $\begin{array}{c}\text { Laba Bersih } \\
\text { (Rupiah) }\end{array}$ & $\begin{array}{c}\text { Total Aset } \\
\text { (Rupiah) }\end{array}$ & $\begin{array}{c}\text { Hasil } \\
\text { Pengembalian } \\
\text { atas Aset (\%) }\end{array}$ & $\begin{array}{c}\text { Rata- } \\
\text { Rata } \\
\text { Industri } \\
(\%)\end{array}$ \\
\hline 2014 & 2.925 .070 .199 & 619.383 .082 .066 & $0,47 \%$ & $3,79 \%$ \\
2015 & -14.056 .549 .894 & 648.899 .377 .240 & $-2,17 \%$ & $8,10 \%$ \\
2016 & 8.813 .611 .079 & 709.959 .168 .088 & $1,24 \%$ & $3,26 \%$ \\
2017 & -24.690 .826 .118 & 780.669 .761 .787 & $-3,16 \%$ & $1,89 \%$ \\
2018 & -114.131 .026 .847 & 648.016 .880 .325 & $-17,61 \%$ & $-1,70 \%$ \\
\hline
\end{tabular}

Sumber : Data diolah Peneliti,2019

Rasio hasil pengembalian atas aset pada tahun 2014 sebesar $0,47 \%$, artinya dengan aset sebesar Rp100,00 maka perusahaan dapat menghasilkan laba bersih sebesar Rp0,47. Pada tahun 2015 sebesar $-2,17 \%$, artinya dengan aset sebesar Rp100,00 maka kerugian yang dialami perusahaan sebesar Rp2,17. Pada tahun 2016 sebesar 1,24\%, artinya dengan aset sebesar Rp100,00 maka perusahaan dapat menghasilkan laba bersih sebesar Rp1,24. Pada tahun 2017 sebesar -3,16\%, 
artinya dengan aset sebesar Rp100,00 maka kerugian yang dialami perusahaan sebesar Rp3,16. Pada tahun 2018 sebesar $-17,61 \%$, artinya dengan aset sebesar Rp100,00 maka kerugian yang dialami perusahaan sebesar Rp17,61. Berdasarkan analisis nilai rasio hasil pengembalian atas selama tahun 2014-2018 cenderung kurang baik jika dibandingkan dengan perusahaan sejenis lainnya karena nilai rasionya masih dibawah rata-rata industri.

\section{2) Hasil Pengembalian atas Ekuitas (Return on Equity)}

Tabel 14. Hasil Perhitungan Rasio Hasil Pengembalian atas Ekuitas PT Martina Berto Tbk Periode 20142018 (Dalam Rupiah)

\begin{tabular}{ccccc}
\hline Tahun & $\begin{array}{c}\text { Laba Bersih } \\
\text { (Rupiah) }\end{array}$ & $\begin{array}{c}\text { Total Ekuitas } \\
\text { (Rupiah) }\end{array}$ & $\begin{array}{c}\text { Hasil } \\
\text { Pengembalian } \\
\text { atas Ekuitas } \\
(\%)\end{array}$ & $\begin{array}{c}\text { Rata- } \\
\text { Rata } \\
\text { Industri } \\
(\%)\end{array}$ \\
\hline 2014 & 2.925 .070 .199 & 453.749 .133 .904 & $0,64 \%$ & $5,38 \%$ \\
2015 & -14.056 .549 .894 & 434.213 .595 .966 & $-3,24 \%$ & $10,90 \%$ \\
2016 & 8.813 .611 .079 & 440.926 .897 .711 & $2,00 \%$ & $4,72 \%$ \\
2017 & -24.690 .826 .118 & 412.742 .622 .543 & $-5,98 \%$ & $2,16 \%$ \\
2018 & -114.131 .026 .847 & 300.499 .756 .873 & $-37,98 \%$ & $-5,74 \%$ \\
\hline
\end{tabular}

Sumber : Data diolah Peneliti,2019

Rasio hasil pengembalian atas ekuitas pada tahun 2014 sebesar 0,64\%, artinya dengan ekuitas sebesar Rp100,00 maka perusahaan dapat menghasilkan laba bersih sebesar Rp0,64. Pada tahun 2015 sebesar $-3,24 \%$, artinya dengan ekuitas sebesar Rp100,00 maka kerugian yang dialami perusahaan sebesar Rp3,24. Pada tahun 2016 sebesar 2,00\%, artinya dengan ekuitas sebesar Rp100,00 maka perusahaan dapat menghasilkan laba bersih sebesar Rp2,00. Pada tahun 2017 sebesar $-5,98 \%$, artinya dengan ekuitas sebesar Rp100,00 maka kerugian yang dialami perusahaan sebesar Rp5,98. Pada tahun 2018 sebesar -37,98\%, artinya dengan ekuitas sebesar Rp100,00 maka kerugian yang dialami perusahaan sebesar Rp-37,98. Berdasarkan analisis, kinerja rasio hasil pengembalian atas ekuitas selama tahun 2014-2018 cenderung kurang baik jika dibandingkan dengan perusahaan sejenis lainnya karena nilai rasionya masih dibawah rata-rata industri.

\section{3) Margin Laba Bersih (Net Profit Margin)}

Tabel 15. Hasil Perhitungan Rasio Margin Laba Bersih PT Martina Berto Tbk Periode 2014-2018 (Dalam Rupiah)

\begin{tabular}{ccccc}
\hline Tahun & $\begin{array}{c}\text { Laba Bersih } \\
\text { (Rupiah) }\end{array}$ & $\begin{array}{c}\text { Penjualan } \\
\text { Bersih (Rupiah) }\end{array}$ & $\begin{array}{c}\text { Margin } \\
\text { Laba } \\
\text { Bersih } \\
(\%)\end{array}$ & $\begin{array}{c}\text { Rata- } \\
\text { Rata } \\
\text { Industri } \\
(\%)\end{array}$ \\
\hline 2014 & 2.925 .070 .199 & 671.398 .849 .823 & $0,44 \%$ & $3,23 \%$ \\
2015 & -14.056 .549 .894 & 694.782 .752 .351 & $-2,02 \%$ & $7,26 \%$ \\
2016 & 8.813 .611 .079 & 685.443 .920 .925 & $1,29 \%$ & $2,82 \%$ \\
2017 & -24.690 .826 .118 & 731.577 .343 .628 & $-3,38 \%$ & $1,59 \%$ \\
2018 & -114.131 .026 .847 & 502.517 .714 .607 & $-22,71 \%$ & $-3,19 \%$ \\
\hline
\end{tabular}

Sumber : Data diolah Peneliti,2019

Rasio margin laba bersih pada tahun 2014 sebesar 0,44\%, artinya dengan penjualan bersih sebesar Rp100,00 maka perusahaan dapat menghasilkan laba bersih sebesar Rp0,44. Pada tahun 2015 sebesar $-2,02 \%$, artinya dengan penjualan bersih sebesar Rp100,00 maka kerugian yang dialami perusahaan sebesar Rp2,02. Pada tahun 2016 sebesar 1,29\%, artinya dengan penjualan bersih sebesar Rp100,00 maka perusahaan dapat menghasilkan laba bersih sebesar Rp1,29. Pada tahun 2017 sebesar $-3,38 \%$, artinya dengan penjualan bersih sebesar Rp100,00 maka kerugian yang dialami perusahaan sebesar Rp3,38. Pada tahun 2018 sebesar $-22,71 \%$, artinya dengan penjualan bersih sebesar Rp100,00 maka kerugian yang dialami perusahaan sebesar sebesar Rp22,71. 
Berdasarkan analisis, kinerja rasio margin laba bersih PT Martina Berto Tbk selama tahun 20142018 cenderung kurang baik jika dibandingkan dengan perusahaan sejenis lainnya karena nilai rasionya masih dibawah rata-rata industri.

\section{KESIMPULAN DAN SARAN}

\subsection{KESIMPULAN}

\section{Rasio Likuiditas}

1. Rasio lancar pada tahun 2014 cenderung lebih baik jika dibandingkan dengan perusahaan sejenis lainnya karena berada diatas rata-rata industri, namun pada tahun 2015-2018 cenderung kurang baik.

2. Rasio cepat pada tahun 2014-2016 cenderung lebih baik jika dibandingkan dengan perusahaan sejenis lainnya karena berada diatas rata-rata industri, namun pada tahun 2017-2018 cenderung kurang baik.

3. Rasio kas pada tahun 2014 cenderung lebih baik jika dibandingkan dengan perusahaan sejenis lainnya karena berada diatas rata-rata industri, namun pada tahun 2015-2018 cenderung kurang baik.

\section{Rasio Solvabilitas}

1. Rasio utang terhadap aset pada tahun 2014 cenderung lebih baik jika dibandingkan dengan perusahaan sejenis lainnya karena berada dibawah rata-rata industri, namun pada tahun 20152018 cenderung kurang baik.

2. Rasio utang terhadap modal pada tahun 2014 cenderung lebih baik jika dibandingkan dengan perusahaan sejenis lainnya karena berada dibawah rata-rata industri, namun pada tahun 20152018 cenderung kurang baik.

\section{Rasio Aktivitas}

1. Perputaran piutang pada tahun 2014-2018 cenderung sedikit kurang baik jika dibandingkan dengan perusahaan sejenis lainnya karena berada dibawah rata-rata industri.

2. Perputaran pada tahun 2014-2017 cenderung lebih baik jika dibandingkan dengan perusahaan sejenis lainnya karena berada diatas rata-rata industri dan pada tahun 2018 cenderung sedikit kurang baik.

3. Perputaran modal kerja pada tahun 2014-2018 cenderung sedikit kurang baik jika dibandingkan dengan perusahaan sejenis lainnya karena berada dibawah rata-rata industri.

4. Perputaran aset tetap pada tahun 2014-2018 cenderung lebih baik karena dibandingkan dengan perusahaan sejenis lainnya dan berada dibawah rata-rata industri.

5. Perputaran total aset pada tahun 2014-2018 cenderung sedikit kurang baik jika dibandingkan dengan perusahaan sejenis lainnya karena berada dibawah rata-rata industri.

\section{Rasio Profitabilitas}

Pada tahun 2014-2018 ketiga rasio profitabilitas yang terdiri dari hasil pengem-balian atas aset, hasil pengembaliatan atas ekuitas dan margin laba bersih pada cenderung kurang baik jika dibanding-kan dengan perusahaan sejenis lainnyakarena berada dibawah rata-rata industri.

Rata-rata industri dalam rasio keuangan yang saat ini digunakan bukan sebagai wujud ukuran atau patokan yang menentukan baik atau buruknya kinerja keuangan perusahaan secara keseluruhan dan realitas, tetapi hanya salah satu barometer secara teroritis. Sebagai alat analisis keuangan, analisis rasio juga memiliki keterbatasan atau kelemahan.

\subsection{Saran}

1. Diperlukan penambahan aset lancar perusahaan sebagai jaminan terhadap utang jangka pendek dan diperlukan penambahan kas dan setara kas yang lebih banyak dan pengendalian terhadap utang jangka pendek.

2. Memberikan pinjaman kepada debitur yang memiliki tingkat rasio solvabilitas yang tinggi menimbulkan konsekuensi bagi kreditor untuk menanggung risiko yang lebih besar pada saat 
debitur mengalami kegagalan keuangan. Oleh sebab itu diperlukan penambahan aset dan ekuitas serta pengendalian terhadap utang jangka panjang.

3. Disarankan bagi perusahan untuk melakukan penagihan piutang secara efektif dan pengelolaan total aset yang baik.

4. Diperlukan peningkatan penjualan dengan memperhatikan trend pasar saat ini agar pemasaran menjadi lebih kreatif sehingga segmentasi pasar semakin bertambah. Selain itu, diperlukan efisiensi biaya pemasaran yang akan menghemat beban penjualan dan pemasaran serta pengelolaan total aset yang maksimal agar berkontribusi pada penjualan.

\section{DAFTAR PUSTAKA}

Bursa Efek Indonesia. Laporan Keuangan \& Tahunan 2016, 2017 dan 2018. www. idx.co.id. Diaksespada 12 Juli - 17 Desember 2019.

Bursa Efek Indonesia. Ringkasan Peforma Perusahaan. www.idx.co.id. Diakses pada 16 Juli \& 18 Oktober 2019.

PT Martina Berto Tbk. Laporan Keuangan \& Tahunan 2014-2018. www.martina berto.co.id. Diakses pada 15 Juli 2019.

Kemendag. Perkembangan Ekspor Non Migas (Komoditi). www.kemendag. go.id. Diakses pada 20 Juli 2019.

Fahmi, I. 2017. Analisis Laporan Keuangan. Cetakan Ke-6. Alfabeta, Bandung.

Hery, 2016. Analisis Laporan Keuangan. PT Gramedia Widiasarana, Jakarta.

Ikatan Akuntan Indonesia. 2018. Pernyataan Standar Akuntansi Keuangan.

Kasmir. 2015. Analisis Laporan Keuangan. PT Raja Grafindo Persada, Jakarta.

Munawir. 2010. Analisis Laporan Keuangan. Liberty, Yogyakarta.

Sugiyono. 2015. Metode Penelitian Kuantitatif, Kualitatif dan R\&D. PT Alfabeta, Bandung. Sukamulja, S. 2019. Analisis Laporan Keuangan sebagai Dasar Pengambilan Investasi. Edisi kesatu. Andi \& BPFE, Yogyakarta.

Subramanyam, K.R., dan Wild, J.J. 2016. Analisis Laporan Keuangan. Cetakan Kedelapan. Salemba Empat, Jakarta.

H. Nathania, A.C .2016. Analisis Laporan Keuangan untuk Menilai Kondisi Keuangan Perusahaan (Studi Kasus pada PT Mustika Ratu Tbk yang terdafar di Bursa Efek Indonesia pada tahun 2011-2014). Skripsi S1. Universitas Sanata Dharma, Yogyakarta.

Maya,L., Nengah, M., dan Husaini, A. 2016. Penggunaan Analisis Rasio Keuangan Untuk Menilai Kinerja Keuangan Perusahaan (Studi pada PT. Semen Indonesia (Persero), Tbk periode 20122014)". Vol. 37 No. 1 Agustus. Halaman 121-128. Universitas Brawijaya, diakses pada tanggal 09 Juli 2019 dari administrasibisnis.studentjournal.ub.ac.id

Setianugraha, H. 2015. Analisis Rasio Keuangan untuk Menilai Kinerja Keuangan Perusahaan (Studi Kasus Pada Perusahaan Pertambangan yang Terdaftar di Bursa Efek Indonesia Tahun 2008-2012). Skripsi S1. Universitas Hasanuddin, Makassar.

Sumiyati 2018. Analisis Laporan Keuangan untuk Menilai Kinerja Keuangan (Studi Kasus PT Indofood Sukses Makmur Tbk). 2018. Skripsi S1. STIE Dewantara, Bogor.

Rini,A.S. 2018. Ini Tantangan yang Dihadapi Industri Kosmetik Nasional. https://ekonomi.bisnis.com/read/20180710/257/815173/ ini-tantangan- yang-dihadapi-industrikosmetik-nasional[15 Juli 2018]

Kemenperin. 2018. Kian Kinclong,Industri Kosmetik Nasional Tumbuh 20 Persen..https://kemenperin.go.id/artikel/18954/Kian-Kinclong,-Industri-Kosmetik-NasionalTumbuh-20- 